\title{
Renewable Energy, Global Warming Problem and Impact of Power Electronics (Invited Paper)
}

\author{
Ahmed. F. Zobaa ${ }^{1}$ and Bimal. K. Bose ${ }^{2}$ \\ ${ }^{1}$ School of Engineering and Design \\ Brunel University \\ Uxbridge, Middlesex, UB8 3PH (UK) \\ Phone: +0044 1895 265335, e-mail: azobaa@ieee.org \\ ${ }^{2}$ Department of Electrical Engineering and Computer Science \\ The University of Tennessee \\ Knoxville, TN 37996-2100 (USA) \\ Phone: +001 865974 8398, e-mail: b.bose@ieee.org
}

\begin{abstract}
Global energy consumption is increasing at a dramatic rate due to the increase in the world's population and the quest for improvement of living standards. Most of our energy comes from fossil fuels which cause the problem of global warming due to the emission of greenhouse gases (GHG). As a result, there are many harmful effects such as rise in sea level, drought in tropical regions near the equator, an increase in hurricanes, tornadoes and floods, and the spread of disease.

Renewable energy is the energy generated from natural resources such as solar heat and light, wind, rain, tides, waves, and geothermal heat, which are replenished naturally. From Wikipedia, in 2008, about 19\% of global final energy consumption came from renewables, with 13\% coming from traditional biomass, used mainly for heating, and 3.2\% from hydroelectricity. New renewables (small hydro, modern biomass, wind, solar, geothermal, and bio fuels) accounted for another $2.7 \%$ and are growing rapidly. The share of renewables in electricity generation is around $18 \%$, with $15 \%$ of global electricity coming from hydroelectricity and 3\% from new renewables.

This paper highlights in particular the impact of power electronics in solving or mitigating the global warming problem and supporting the generation of renewable energy [1]-[30].
\end{abstract}

\section{Key words}

Renewable Energy, Global Warming, Power Electronics.

\section{Introduction}

Global energy consumption is increasing dramatically due to our quest for higher living standards and an increasing world population. Most of our energy comes from fossil fuels, and burning these fuels causes global warming. Global warming raises the sea level, brings drought to tropical regions near the equator, increases hurricanes, tornadoes and floods, and spreads disease.
These consequences are serious and will eventually bring tremendous unrest in the world. Various measures to solve or mitigate global warming are outlined in the paper.

Power electronics help improve the energy efficiency of apparatus, and helps the generation of environmentally clean or green energy. Renewable green energy sources will constitute the bulk of our energy sources in the future. It has been estimated that widespread energy efficiency improvement, by power electronics and other methods with the existing technologies, can save $20 \%$ of global energy demand, and another $20 \%$ can be saved by preventing waste, i.e., by various conservation methods. "Global warming problem is solvable by the united effort of humanity" [4].

\section{World Energy Outlook}

Demand for coal, shown in Fig. 1, has been growing faster than any other energy source, and is projected to account for more than a third of incremental global energy demand by 2030. World reserves of coal are very large and will last for 200 years at the current rate of consumption.

Oil demand, shown in Fig. 2, will peak at $88 \mathrm{mb} / \mathrm{d}$ before 2020 and then fall to $81 \mathrm{mb} / \mathrm{d}$ by 2035, with a plunge in OECD demand more than offsetting continuing growth in non-OECD demand. World reserves of oil will last for 40 years at the current rate of consumption. But that has been the situation for many years. In other words, until now, the oil consumed was able to be replaced by new reserves.

Gas demand, shown in Fig. 3, will increase from 108 trillion cubic feet in 2007 to 156 trillion cubic feet in 
2035. World reserves of gas will last for 60 years, at 2005 consumption levels. In other words, the issues surrounding the future of natural gas are the same as those for oil, but with a delay of an additional 20 years or so.

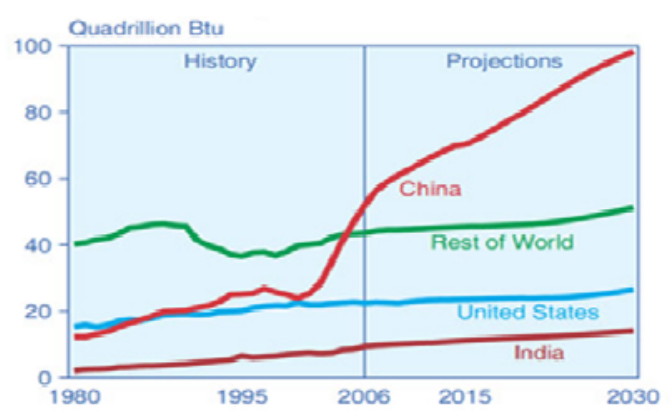

Fig. 1. Coal Demand [2]

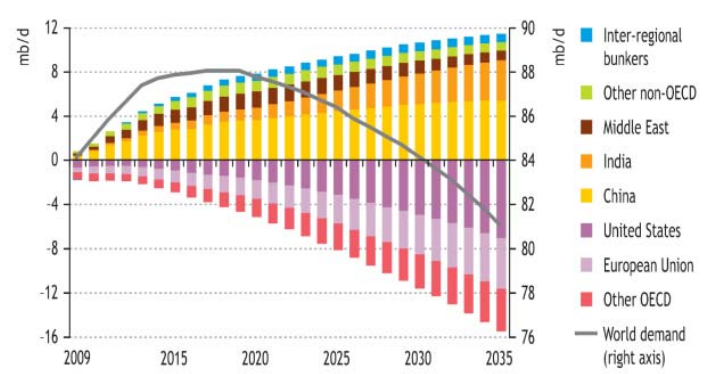

Fig.2. Oil Demand [2]

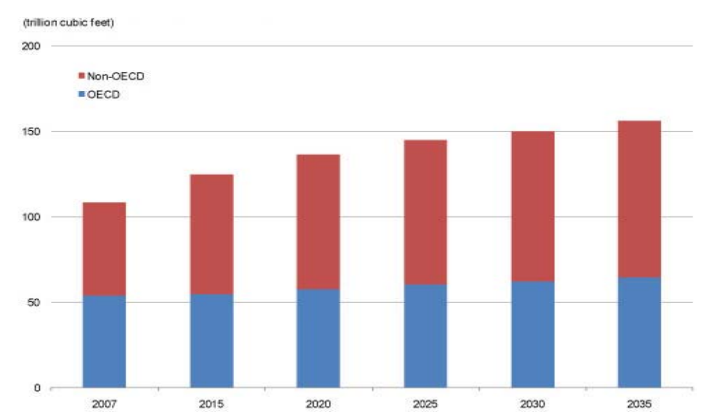

Fig.3. Gas Demand [2]

World energy demand, shown in Fig. 4, will expand by 60\% between 2003 and 2030.

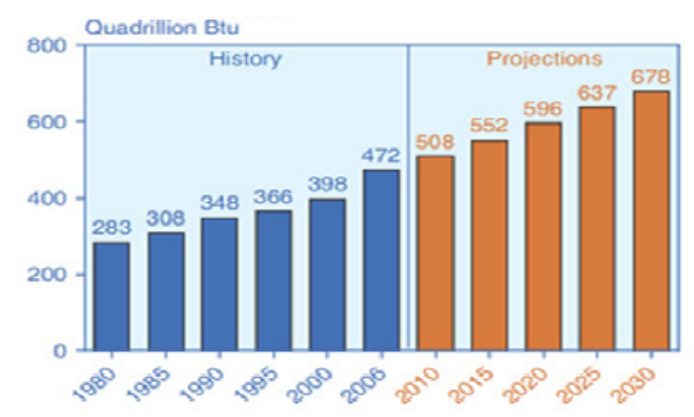

Fig. 4. World Energy Demand [2]
After 2020, renewables are expected to become the second largest source of electricity behind coal, as shown in Fig. 5.

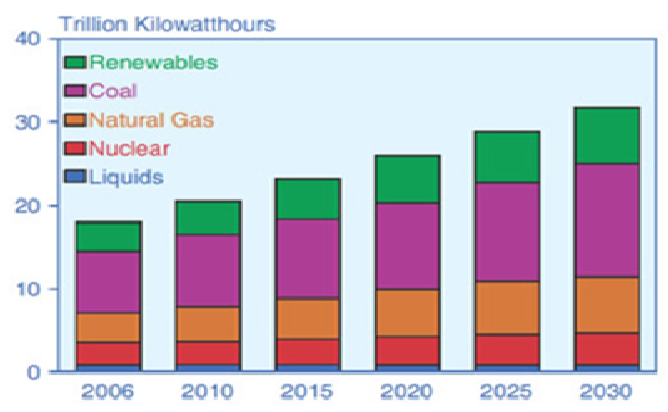

Fig. 5. World Electricity Generation [2]

Nuclear energy, shown in Fig. 6, does not have the traditional environmental pollution problem, but the safety aspects of nuclear plant, in terms of radiation hazard and radioactive waste, are of serious concern.

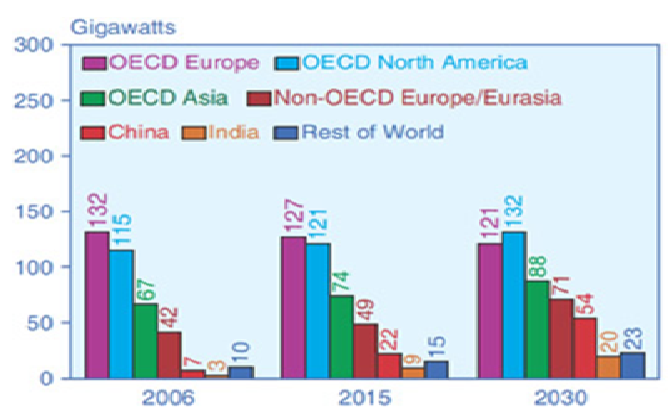

Fig. 6. World Nuclear Energy [2]

Renewables, shown in Table I, are the fastest-growing source of world energy, with their consumption increasing by $3 \%$ per year.

Table I. World Renewable Energy Generation [2]

\begin{tabular}{|lrccc|}
\hline & \multicolumn{2}{c}{2002} & \multicolumn{2}{c|}{2030} \\
& $\begin{array}{c}\text { Electricity } \\
\text { generation }\end{array}$ & $\begin{array}{c}\text { Share } \\
\text { in total } \\
\text { renewables } \\
(\%)\end{array}$ & $\begin{array}{c}\text { Electricity } \\
\text { generation }\end{array}$ & $\begin{array}{c}\text { Share } \\
\text { in total } \\
\text { renewables } \\
(\%)\end{array}$ \\
\hline Hydropower & 2610 & 89 & 4248 & 69 \\
Biomass & 207 & 7 & 627 & 10 \\
Wind & 52 & 2 & 929 & 15 \\
Geothermal & 57 & 2 & 167 & 3 \\
Solar & 1 & 0 & 119 & 2 \\
Tide/wave & 1 & 0 & 35 & 1 \\
\hline Total & 2927 & 100 & 6126 & 100 \\
\hline
\end{tabular}

\section{Global Warming Problem}

Undoubtedly, energy is the lifeblood of the continued progress of human civilization. Per capita energy consumption is the barometer of a nation's prosperity. Global energy consumption has increased dramatically to accelerate our living standard. The USA with $5 \%$ of the world's population, consumes $25 \%$ of total energy. Japan with $2 \%$ of the world's population consumes $5 \%$ of total energy. China and India with $35 \%$ of the world's 
population consume only $3 \%$ of total energy. But this scenario is changing fast.

The Earth's atmosphere accumulates solar heat due to GHG concentrations and raises the temperature. This causes:

- $\quad$ melting of glaciers and polar ice caps

- inundation of low-lying areas

- $\quad$ adverse effect on world climate

- severe drought in tropical countries near the equator that damages agriculture and vegetation

- hurricanes, tornados, heavy rain and floods

- $\quad$ spread of disease

- extinction of some animal species

- $\quad$ acidity increase in seawater.

According to UN predictions, some example scenarios due to global warming are:

- $\quad 50 \%$ of Bangladesh will be under water in 300 years displacing $75 \mathrm{M}$ people

- Several island nations in the Pacific will be under water within 100 years.

- India's agricultural production will decrease by $38 \%$ by 2080 due to drought, but $\mathrm{CO}_{2}$ fertilization will offset it by $9 \%$

- Melting of ice in Antarctica and Greenland will cause ocean level rise by $200 \mathrm{ft}$.

- Melting of all the ice in the world will cause ocean level to rise by $210 \mathrm{ft}$.

- Arctic regions will be virtually free of ice by 2070

- If fossil fuel burning is completely stopped today, ocean level will rise by $4.6 \mathrm{ft}$. in next 1000 years

Table II presents the top six emitting countries.

Table II. Top 6 Emitting Countries [2]

\begin{tabular}{|c|c|c|c|}
\hline Country & $\begin{array}{c}\text { Share GHG } \\
2005\end{array}$ & $\begin{array}{c}\text { Share } \mathrm{Co}_{2} \\
2005\end{array}$ & $\begin{array}{c}\text { Share } \mathrm{Co}_{2} \\
2009\end{array}$ \\
\hline China & $17 \%$ & $20 \%$ & $26 \%$ \\
\hline USA & $15 \%$ & $20 \%$ & $17 \%$ \\
\hline EU-27 & $11 \%$ & $14 \%$ & $12 \%$ \\
\hline Russia & $5 \%$ & $6 \%$ & $5 \%$ \\
\hline India & $5 \%$ & $4 \%$ & $5 \%$ \\
\hline Japan & $3 \%$ & $5 \%$ & $4 \%$ \\
\hline
\end{tabular}

Note that human beings and other animals exhale GHG, but the trees absorb $\mathrm{CO}_{2}$ by photosynthesis (called the carbon fertilization effect). Some $\mathrm{CO}_{2}$ is washed away by rain and dissolves as carbonic acid in the ocean. In normal conditions, different natural sources and sinks of GHG maintain the ecological balance that maintains the stable atmospheric temperature.

\section{The Impact of Power Electronics}

The modern era of high density solid state power electronics started with the invention of PNPN triggering transistor by Bell Labs (1956), which was later translated into the commercial thyristor (1958) by GE. Since then, there has been a vast expansion in the technology with the $R \& D$ radiating in different directions (power semiconductor devices, converter topologies, analytical \& simulation techniques, estimation, control techniques, control hardware and software). It is interesting to note that the name "Power Electronics" emerged systematically from the early 1970s. Earlier, it was included as a part of Industrial Electronics.

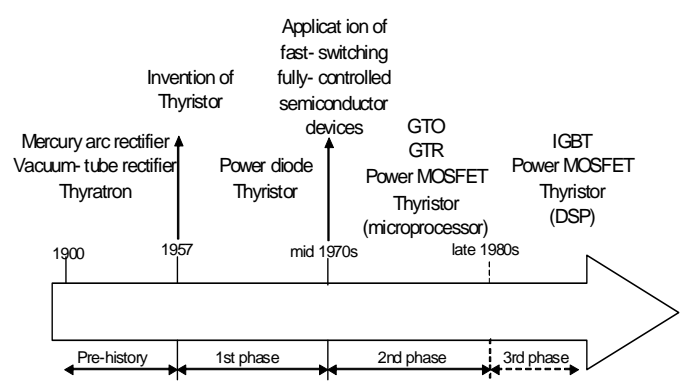

Fig. 7. Evolution of Power semiconductor devices

Power Electronics is an exciting, but complex technology, because of its multi-disciplinary nature. It is currently the most active discipline in electric power engineering, as indicated in Fig. 8.

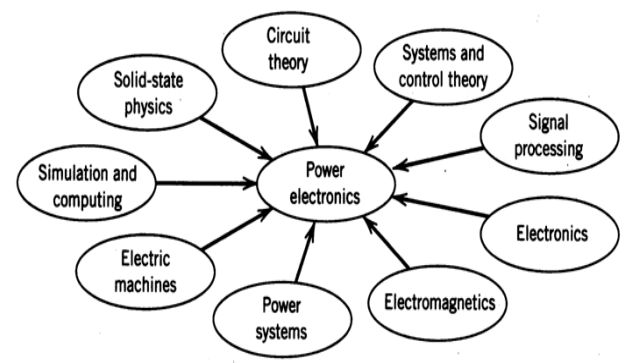

Fig. 8. Multi-disciplinary Nature of Power Electronics [30]

Power electronics is the interface between electronics and power, as shown in Fig. 9.

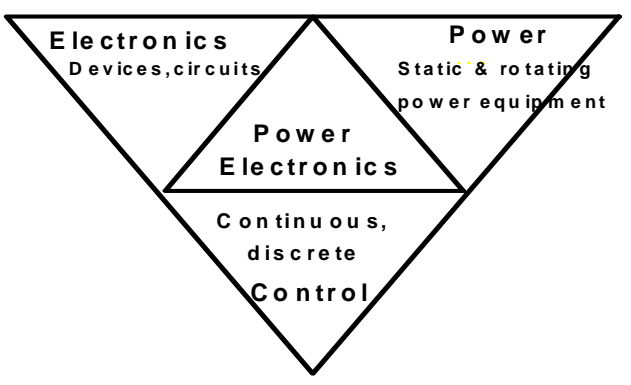

Fig. 9. Interface between Electronics and Power 
The applications of power electronics may include dc and ac regulated power supplies, uninterruptible power supply (UPS) systems, electrochemical processes (such as electroplating, electrolysis, anodizing, and metal refining), heating and lighting control, electronic welding, power line static VAR compensators [SVCs, static VAR generator, or static synchronous compensator (STATCOM)], active harmonic filters, high voltage dc (HVDC) systems, photovoltaic (PV) and fuel cell (FC) power conversion, solid state dc and ac circuit breakers, high-frequency heating, and motor drives. The motor drive area may include applications in computers and peripherals, solid state starters for motors, transportation (electric/hybrid electric vehicles (EV/HEV), subway, etc.), home appliances, paper and textile mills, wind generation system, air-conditioning and heat pumps, rolling and cement mills, machine tools and robotics, pumps and compressors, ship propulsion, etc. In addition to applications in energy systems and industrial automation, power electronics is now playing a significant role in global energy conservation that is helping environmental pollution control indirectly, i.e., solving the global warming problem [29]. It is also an important player enabling the better utilization of renewable energy sources by implementing maximum power point tracking (MPPT) function (for wind and photovoltaic), ride-through capabilities, etc. Power converters are capable of seamlessly transferring variable frequency power to the fixed frequency grid (ac-dc-ac). It is critical for wind energy and hydro-energy. Economical storage solutions can increase the capacity factor of renewable energy sources like wind and PV and increase their penetration in the grid. Distributed power generation systems will provide solutions to avoid energy crises in the future. It will increase the power production in the vicinity of the consumption centers. In the long-term, it will decrease the power volume at the transmission level and make the central grid control very complex. Local grid control will be necessary in order to avoid grid instability and blackout. New control methods appear to improve performance. The future distributed generation is able to run in on-grid and off-grid modes. Advanced control of grid converters, including grid impedance estimation, adaptive current control, are emerging. Monitoring and advanced diagnosis will also be integrated.

The solutions to solve global warming problems include:

- Widespread promotion of renewable energy

- Applying advanced emission control standards to fossil fuel based power generating stations

- Promotion of Electric Vehicles. (The ICE vehicles will be replaced by electric vehicles with the intermediate step of hybrid vehicles

- Widespread mass transportation (as in Japan and Europe)

- Promotion of energy efficiency in the generation, transmission, distribution and utilization of electrical energy.

\section{A. Variable-frequency drives}

According to the estimate of the Electric Power Research Institute (EPRI), USA, around $60 \%$ to $65 \%$ of grid energy in USA is consumed in electrical machine drives, and $75 \%$ of these are pump, fan, and compressor-type drives. The majority of the pumps and fans are used in the industrial environment for control of fluid flow. It is reported that, currently, around $97 \%$ of medium to highpower drives for such applications operate at fixed speed [29], so only $3 \%$ of these drivers operate at variable frequency speed control. In a variable frequency drive, converter-machine efficiency can be improved further by machine flux programming at light load and reduced speed. Power electronics-based loadproportional speed control in air-conditioning can save as much as $30 \%$ of energy, compared to the traditional thermostatic control. The additional cost of power electronics can be recovered by saving energy in a period depending on the cost of electricity [29].

\section{B. Lighting:}

Approximately $24 \%$ of grid energy in the USA is consumed in lighting. Power electronics-based highfrequency compact fluorescent lamps (CFLs) can, typically, be four times more efficient than traditional incandescent lamps, besides giving much longer life. Light dimming control of CFL can further improve energy efficiency. The CFLs are expected to completely replace the incandescent lamps in the near future. Solidstate LED lamps with higher efficiency and longer life are becoming more popular:

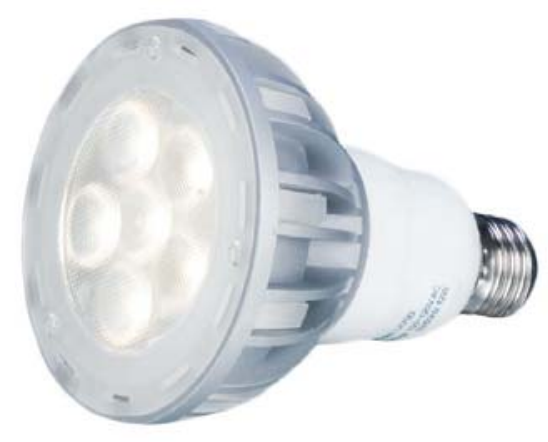

Fig. 10. A solid-state LED lamp (Courtesy of [5])

According to the EPRI estimate, 15\% of grid energy can be saved easily by widespread (but economical) applications of power electronics [29].

\section{Wind Energy}

One of the best sources of renewable energy is wind energy. Wind energy has the biggest share in the renewable energy sector. Over the past 20 years, gridconnected wind capacity has more than doubled and the cost of power generated from wind energy based systems has reduced to one-sixth of the corresponding value in the early 1980 s. 
Early versions of wind turbine generators consisted of fixed-speed wind turbines with conventional induction generators. This class of machines was rugged but was limited to operation in a narrow wind-speed range. In addition, the conventional induction generator, which was connected directly to the electrical grid, required that reactive power support be provided locally to achieve the desired voltage level.

Advances in power electronics have revolutionized wind turbine technology and led to the development of the doubly fed induction generator (DFIG) (Fig. 11).

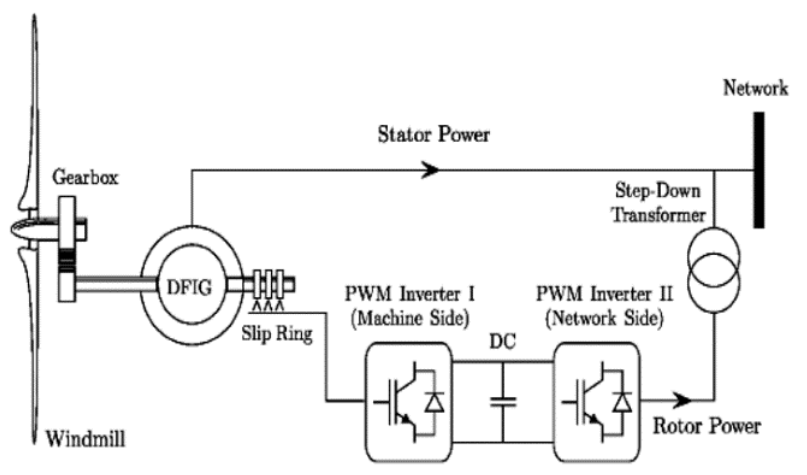

Fig. 11. Schematic drawing of a doubly fed induction generator wind turbine. (Courtesy of [6])

The stator of the DFIG is connected directly to the grid, and the rotor winding is connected via slip rings to a converter. The highly efficient, variable speed DFIG is designed to get maximum energy from the wind, and puts out electricity at a constant frequency, no matter what the wind speed [26].

Fig. 12 depicts this variable speed wind energy conversion system in a block diagram.

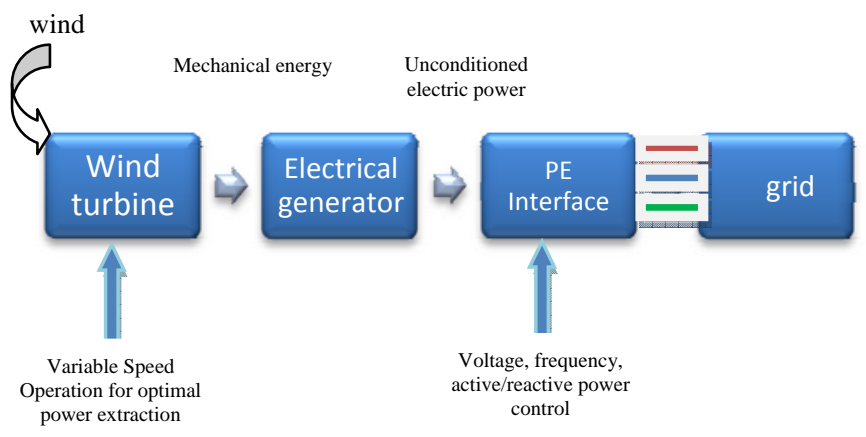

Fig. 12 Variable speed wind energy conversion system.

(Courtesy of [7])

Fig. 13 depicts the same figure as Fig 11 but in a different representation. It shows a doubly-fed-induction generator where the rotor circuit is controlled by the power converter system via the slip rings, and the stator circuit is connected to the grid. This method is advantageous as the power converter has to handle a fraction $\sim 25 \%-50 \%$ of the total power of the system. The power converter system employs a rotor side ac-dc converter, a dc link capacitor, and a dcac inverter connected to the grid as shown in Fig. 13. The power converter enables vector control of the field which facilitates active/reactive power control.

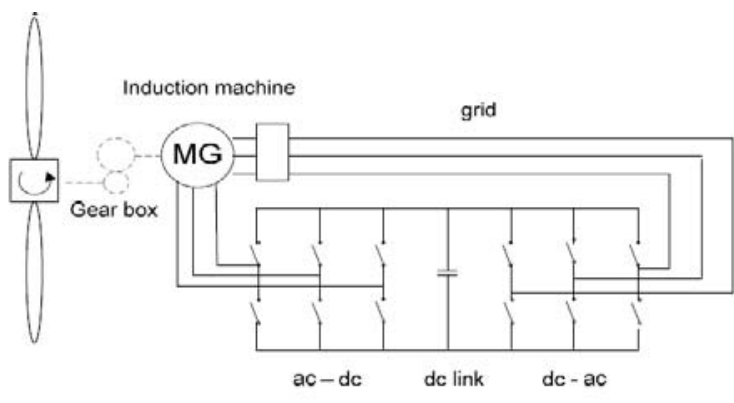

Fig. 13 Limited range, variable wind energy conversion system. (Courtesy of [7])

On the other hand, in Fig. 14 the wind turbine can be completely decoupled from the grid, enabling a wider range of optimal operation.

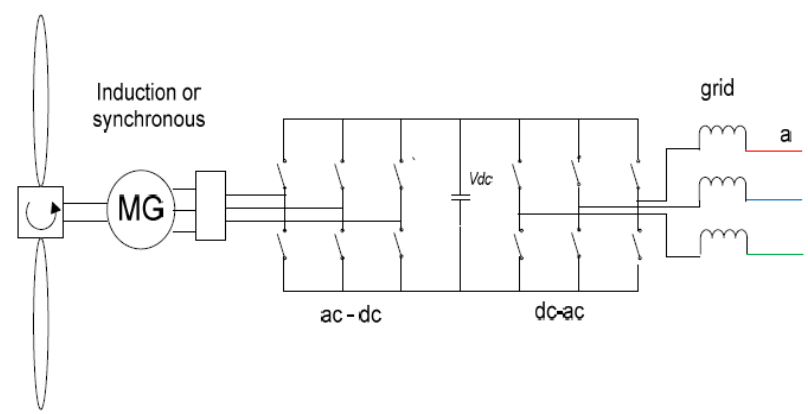

Fig. 14. Fully variable wind energy conversion system. (Courtesy of [7])

A Z-source inverter based conversion system is a more novel conversion system making the role of power electronics more clear. Fig. 15 illustrates its topology.

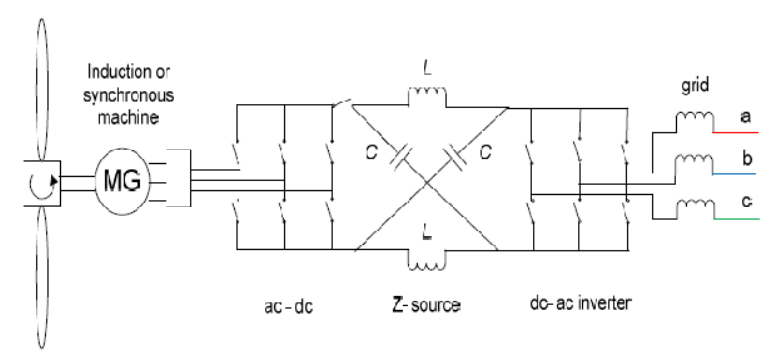

Fig. 15. Z-source based variable speed wind energy conversion system. (Courtesy of [7])

The following lists some merits of this topology.

- $\quad$ Buck-boost ability.

- Inherent short circuit protection due to Z-source configuration.

- $\quad$ Improved EMI as dead bands are not required [21].

Most modern wind farms have DFIGs and are available in ratings that range from 1.5 megawatts (MW) to 4.5 MW. Newer generations of wind generators, which have permanent magnet synchronous generators and fully 
rated converters, have a range of control over both real power and reactive power for varying wind speeds.

\section{Fuel Cell System}

A fuel cell is an electrochemical cell that converts energy from a fuel into electrical energy. Electricity is generated from the reaction between a fuel supply and an oxidizing agent. The reactants flow into the cell, and the reaction products flow out of it, while the electrolyte remains within it. Fuel cells can operate continuously as long as the necessary reactant and oxidant flows are maintained [23].

Fuel cells are different from conventional electrochemical cell batteries. Fuel cells consume reactants that must be replenished, while batteries store electrical energy chemically in a closed system [24].

Fuel cells can be used in electric vehicles, building cogeneration, portable power sources, UPS systems, and distributed power generation for utility systems [29].

Currently, there are a large number of corporations involved in fuel cell technology, such as Sony, Honda, Mobion, Angstrom, Volkswagen and InnovaTek.

Sony showed the world a prototype of its developed micro-size fuel-cell system in 2008.

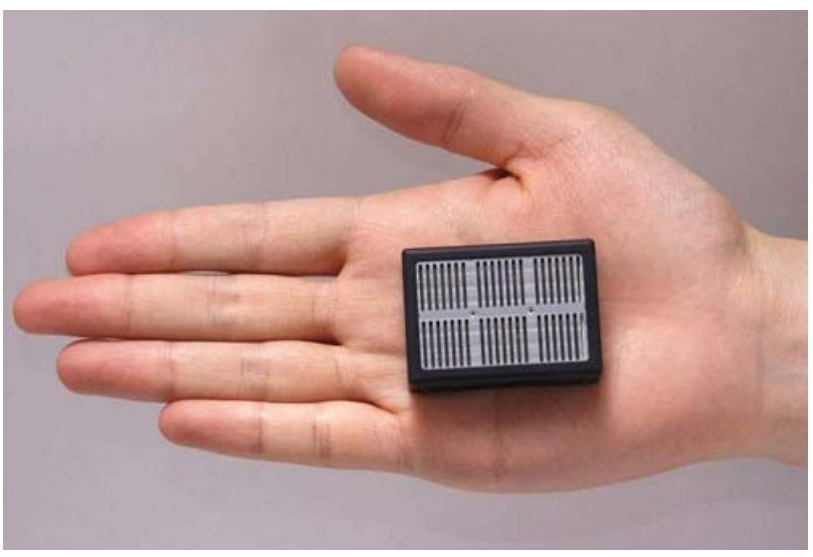

Fig. 16. Sony micro fuel cell system. (Courtesy of [8])

The micro fuel cell uses methanol directly as fuel and it is an active fuel-cell system, which controls fuel supply with a pump. With $10 \mathrm{~mL}$ of methanol, the device can supply enough power for a mobile phone to play 1seg movies for fourteen hours.

Fuel cells are made up of three segments which are placed together: the anode, the electrolyte, and the cathode. Two chemical reactions happen at the interfaces of the three different segments. The net result of the two reactions is that fuel is consumed, water or carbon dioxide is created, and an electric current is created, which can be used to power electrical devices, normally referred to as the load. At the anode a catalyst oxidizes the fuel, usually hydrogen, turning the fuel into a positively charged ion and a negatively charged electron. The electrolyte is a substance which ions can pass through, but electrons cannot. The freed electrons travel through a wire creating the electric current. The ions move through the electrolyte to the cathode. Once they reach the cathode, the ions are reunited with the electrons and the two react with a third chemical, usually oxygen, to create water or carbon dioxide. [25]

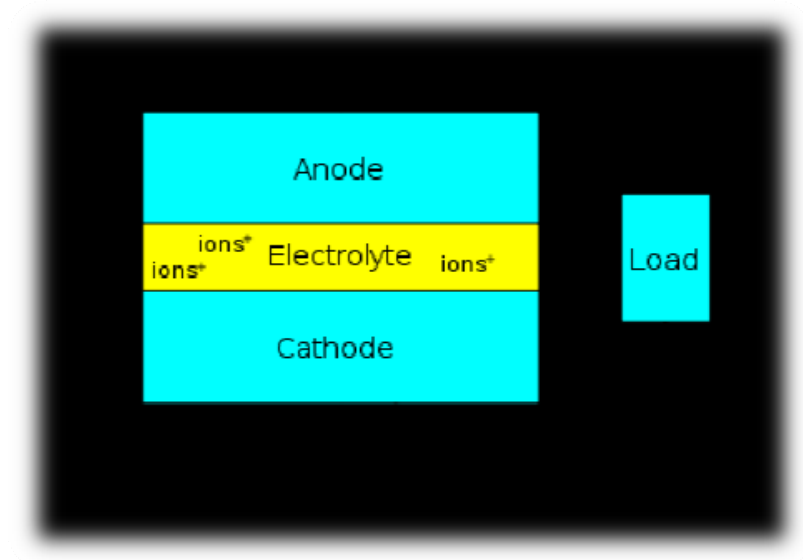

Fig. 17. A block diagram of a fuel cell. (Courtesy of [9])

Fuel cells are characterized by their electrolyte material; the SOFC has a solid oxide or ceramic electrolyte. Advances in solid oxide fuel cell technology has resulted in the emergence of high temperature solid oxide fuel cells (SOFCs). They offer a clean, pollution-free technology to generate electricity electrochemically at high efficiencies. Furthermore, because of their high temperature of operation ( 1000 degree Celsius), natural gas fuel can be reformed within the cell stack, eliminating the need for an expensive, external reformer system. Also, pressurized SOFCs can be used successfully as replacements for combustors in gas turbines; such hybrid SOFC-gas turbine power systems are expected to reach efficiencies approaching 70\% [29].

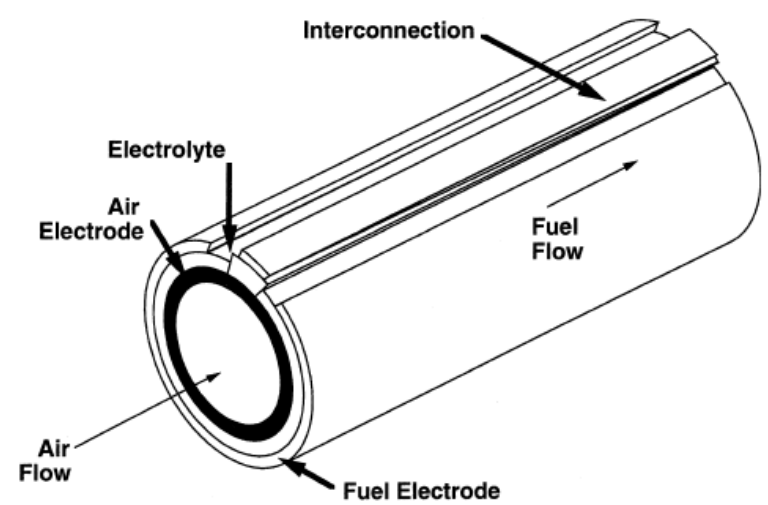

Fig. 18. Tubular solid oxide fuel cell design. (Courtesy of [10])

Fig. 18 illustrates the design of the tubular geometry cell. In this design, the cell components are deposited i.e. oxygen in the gas phase is reduced to oxide ions in the form of thin layers on a ceramic cathode (air consuming two electrons in the process: the air electrode) tube [29]. Since 1984, successively larger size SOFC power generation systems have been designed, built, and tested. Recently, two 25kW systems, each consisting of 576 
$50 \mathrm{~cm}$ active length cells (with EVD electrolyte, EVD fuel electrode, and plasma sprayed interconnection), were built and operated. One system was operated at the Southern California Edison Company's Highgrove Generating Station in Grand Terrace (near San Bernardino), California, under a program with the US Department of Defence's Advanced Research Projects Agency (ARPA). In addition to the SOFC generator, this system also consisted of a logistic fuel processor, located externally from the SOFC stack, enabling the system to operate on either natural gas or on reformate from a logistic fuel (DF2 diesel or JP-8 jet turbine fuel). This system was operated successfully for $5582 \mathrm{~h}$ before the project completion in early 1996; 766 h on jet turbine fuel, 1555 h on diesel fuel, and $3261 \mathrm{~h}$ on natural gas. During this time, the system endured five thermal cycles to room temperature, produced up to $27 \mathrm{~kW}$ on each of the three fuels, and showed no evidence of performance degradation. In January 1998, without any modifications to the SOFC generator, the system was restarted on natural gas at the National Fuel Cell Research Center at the University of California, Irvine. [29]

The other system, built for a consortium of Osaka Gas and Tokyo Gas, completed $13194 \mathrm{~h}$ of successful operation on desulfurized natural gas with $0.1 \%$ per $1000 \mathrm{~h}$ of performance degradation. During this period, the unit achieved $25 \mathrm{~kW}$ of power output and endured 10 thermal cycles to ambient temperature. A $100 \mathrm{~kW}$ SOFC power generation system began operation in December 1997 in The Netherlands under a program with a consortium of Dutch and Danish utilities (EDB/ELSAM). This system is installed and operated in Westervoort near Arnhem, at a district heating system owned by NUON, one of the groups of five Dutch gas and electricity distribution utilities which belong to the EDB consortium. The system employs 1152 state-of-the-art cells (2.2 cm diameter, 150 $\mathrm{cm}$ active length); these cells are prototypic of the cells that are planned to be used in commercial SOFC generators. The system is currently delivering over $100 \mathrm{~kW}$ AC to the grid at an efficiency of $43 \%$ (AC/LHV). In addition, it is producing $85 \mathrm{~kW}$ of hot water for the local district heating system, yielding a total fuel effectiveness (at $100 \mathrm{~kW} \mathrm{AC)} \mathrm{of} 73 \%$. The maximum power output of the system is $160 \mathrm{~kW}$ net AC. Such atmospheric SOFC systems with electrical generation efficiencies (AC/LHV) in the $45-50 \%$ range are ideally suited for distributed power generation and cogeneration. The systems described above have been operated at 1 atmosphere pressure. Elevated pressure SOFCs in conjunction with a gas turbine (GT) have the potential to provide still higher power generation efficiencies. Such hybrid systems can be configured in a number of ways depending upon the turbine selected and the capacity required. In the simplest recuperated SOFC/GT configuration, efficiencies of 60$65 \%$ can be achieved. If a reheat cycle is used with a split shaft turbine, efficiencies greater than $70 \%$ are possible. Megawatt-class commercial SOFC-GT power systems are expected to be price-competitive with other power generation systems of comparable size because of their high efficiency, high availability and low maintenance costs. A $250 \mathrm{~kW}$ hybrid pressurized SOFC-GT power generation system is presently being fabricated in a program with Edison Technology Solutions (ETS) for proof-of-concept testing. The system will integrate a 200kW SOFC stack (1152 cells of $2.2 \mathrm{~cm}$ diameter and $150 \mathrm{~cm}$ active length) operating at about 3.5 atmosphere pressure with a $50 \mathrm{~kW}$ micro turbine generator. It is expected to achieve an electrical efficiency of 57\% (net AC/LHV).

\section{E. Renewable Energy through Micro Inverters}

A relatively new option for optimizing solar system efficiency and reliability is use of micro-inverters that connect to each individual solar panel. Equipping each panel with its own micro-inverter allows the system to accommodate its changing load and atmospheric condition, which provides optimal conversion efficiency for both the individual panels and the entire system [22]. Power inverters are the critical electronic component in a solar power system. In commercial applications, these components interface with the photovoltaic (PV) panel, the batteries that store the charge and the local power distribution system or the public utility grid [22].

Fig. 19 shows a typical solar inverter, which takes a very low voltage from the dc output of a PV array and converts it into some combination of dc battery voltages, ac line voltages and distribution grid voltages [22].

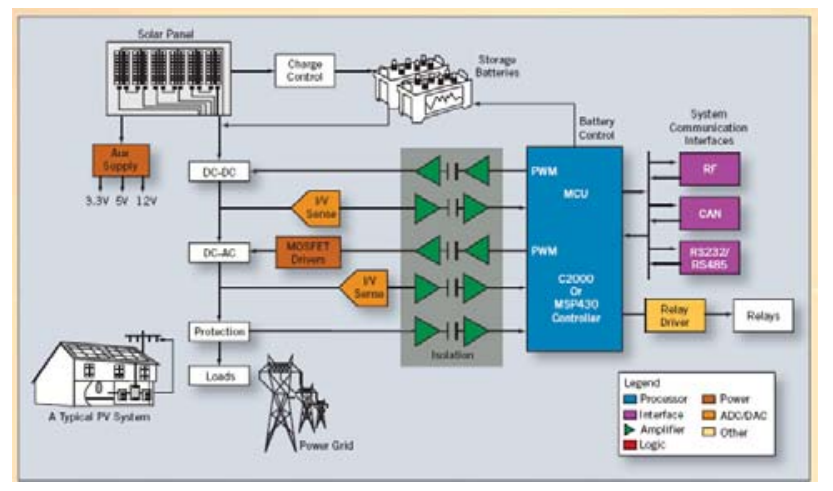

Fig. 19. Conventional power converter architecture. (Courtesy of [11])

It should be noted that in Fig.19, the microcontroller (MCU) block, TMS320C2000 or MSP430 microcontrollers typically include such critical on-chip peripherals as pulse-width-modulation (PWM) modules and $\mathrm{A} / \mathrm{D}$ converters.

Furthermore, in a typical solar energy-harvesting system, multiple solar panels are connected in parallel to a single inverter that converts the variable dc output of multiple PV cells into a clean sinusoidal $50-\mathrm{Hz}$ or $60-\mathrm{Hz}$ voltage source. This is usually done by MPPT algorithms and other techniques which increase efficiency and maximize conversion efficiency [22].

On the other hand, using a micro-inverter for each individual solar panel instead of using a single inverter for the entire system can prove beneficial in reducing different control requirements, such as the ability to adjust conversion parameters on each panel using a highresolution PWM.

Micro-inverter architectures employ a dedicated MCU for each panel to manage energy conversion. However, 
these additional MCUs can also be used to improve both system and panel monitoring. Besides, the MCU is integrated on-chip communication peripherals (CAN, SPI, UART, etc.), in order to simplify interfacing with other micro-inverters in the solar array [22].

\section{MCU Features:}

The main obligation of MCU is load balancing. The MCU detects the load current, and increases or decreases the output voltage by turning off the output MOSFET. This requires a fast on-chip $\mathrm{ADC}$ to sample the voltage and current. Here are some of the MCU (Piccolo series) capabilities:

- Supports a variety of protocols, such as power line communications (PLCs) and controller area networks (CANs)

- a high-performance PWM capability, fast ADC and high-performance CPU

- $\quad$ software programmability

- integrated dual on-chip $10-\mathrm{MHz}$ oscillators for clock comparison

- on-chip $\mathrm{V}_{\mathrm{REG}}$ with power-on reset and brown-out protection

- multiple high-resolution 150-ps PWMs

- a 12-bit, 4.6 mega-sample/s ADC and interfaces for the $\mathrm{I}^{2} \mathrm{C}$ (PMBus), CAN, SPI, and UART communications protocols [22]

Fig. 20 shows a computer system configuration for use with a micro-inverter-based PV system.

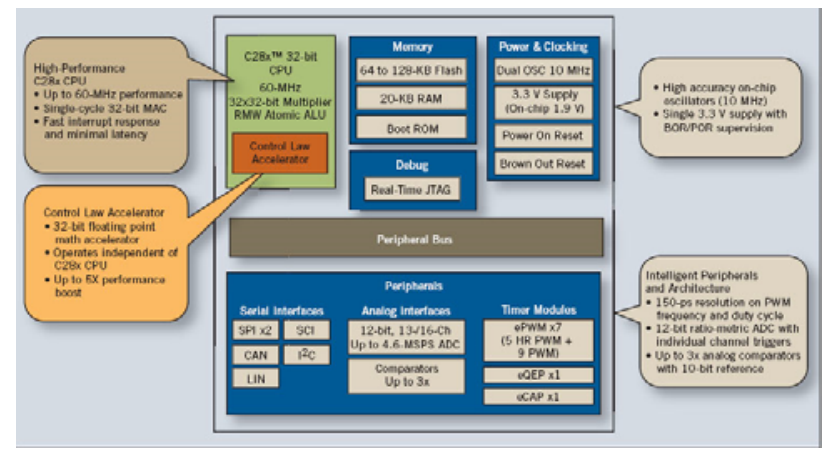

Fig. 20. MCU system configuration for a micro-inverter-based PV system. (Courtesy of [12])

\section{F. Solar Energy}

The use of solar energy is heavily dependent on power electronics. The conversion of solar energy to electricity is currently accomplished mostly in two ways: by direct conversion using photovoltaics (PVs), or by solar thermal conversion. These are briefly described below.

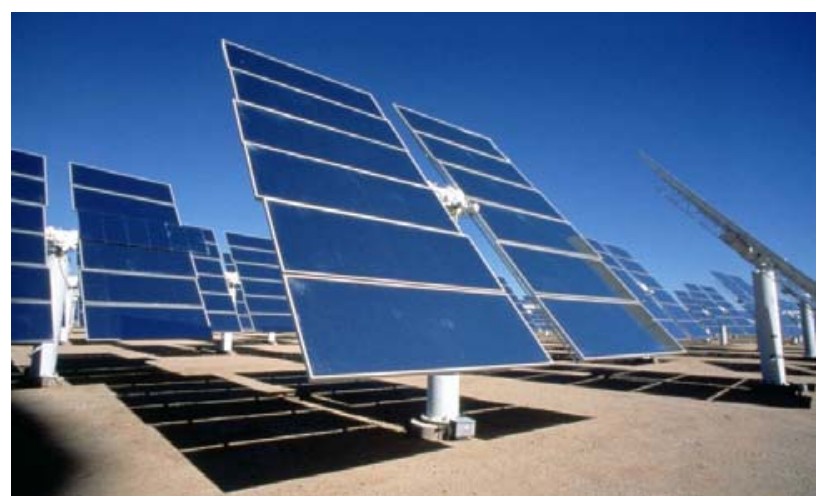

Fig. 21. Photovoltaic panels. (Courtesy of [13])

In the direct-conversion method, PVs generate a direct current (DC) output that is converted to alternating current (AC). This conversion is achieved by a power electronic device called an inverter. Most PVs are rooftop units, and PV-based solar energy primarily has limited distribution and capacity. However, some large commercial PV-based solar facilities of up to $60 \mathrm{MW}$ have been built recently.

\section{Solar Thermal Conversion:}

In solar thermal conversion, the sun's rays are directed by mirrors to heat a thermal exchange agent (e.g., mineral oil) to a sufficiently high temperature. This agent then exchanges the heat generated via a conventional steam cycle and runs a steam turbine that drives a synchronous generator.

The solar thermal method also has the capability of storing energy using a thermal phase-transition approach. This is commonly achieved by using molten salt to store heat for up to six hours; the stored heat is used to run a conventional steam cycle when energy from the sun is not available. Although solar thermal facilities have plant capacities in the range of several hundred MWs, they also require significant quantities of water for cooling and steam generation. Unfortunately, water resources are limited in many parts of the United States where solar radiation is plentiful [26].

\section{Power Electronics in Electric Vehicles}

An electric vehicle (EV), also referred to as an electric drive vehicle, uses one or more electric motors. Electric vehicles include electric cars, electric trains, electric lorries, electric aircraft, electric boats, electric motorcycles and scooters, and electric spacecraft.

Burning fuel in a small, mobile engine is inefficient compared to industrial power generators. If the electricity used is generated from wind, solar, waves, tide or nuclear fuel then electric cars have zero emissions. Either way, air quality improves dramatically in cities and consequently the greenhouse gas emission decreases. The penetration of electric vehicles in today's market is still not considerable and fossil fuels such as petroleum comprise most of the required fuel for transportation. In 2005, the United States used 570 billion liters of petroleum for transportation; if current trends persist this 
will rise to 745 billion liters per year in 2025, and nearly 1 trillion liters in 2050 [30].

From a more global perspective, the problem will worsen in the future, due largely to the rapid rate of motorization and industrialization in China and India.

Fig. 22 shows the increase in vehicles during the years 2000 to 2050.

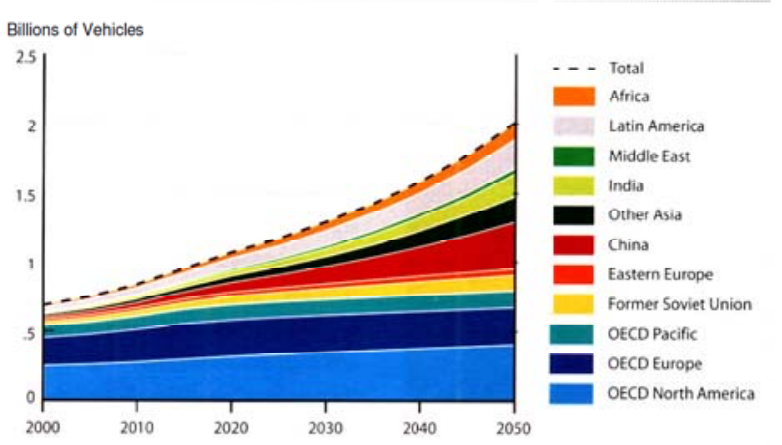

Fig 22. Worldwide growth in number of vehicles, 2000-2050. (Courtesy of [18])

In the past few years, power device technology has made tremendous progress. These power devices have grown in power rating and performance by an evolutionary process. The recently introduced power devices are the gate-turnoff thyristor (GTO), power bipolar-junction transistor (BJT), power metal-oxide field-effect transistor (MOSFET), insulated-gate bipolar transistor (IGBT), static-induction transistor (SIT), static-induction thyristor (SITH), and MOS-controlled thyristor (MCT). Active research is still being pursued on the development of high-performance power devices. The selection of power devices for EV propulsion is generally based on the requirements of the voltage rating, current rating, switching frequency, power loss, and dynamic characteristic.

The voltage rating depends on the battery nominal voltage, maximum voltage during charging, and maximum voltage during regenerative braking. The current rating depends on the motor peak power rating and number of devices connected in parallel. The switching frequency should be high enough to reduce the acoustic noise, size of filters, and EMI problem. On the other hand, higher switching frequencies increase the switching loss. Since an extra $1 \%$ efficiency in EV propulsion can enable an additional few miles in the EV driving range, the power loss, including both switching and conduction losses, should be minimal. The dynamic characteristic should be good enough to allow for high dv/dt capability, simple driving, and easy paralleling. The device protection, packaging, reliability, and cost should also be considered [28].

Among the available power devices, the GTO, BJT, MOSFET, IGBT, and MCT are particularly suitable for $\mathrm{EV}$ propulsion. Some of their operating characteristics are given in Table III.
Table III. Comparison of Power Devices For EV Propulsion.(Courtesy of [19])

\begin{tabular}{c|c|c|c|c|c|c} 
& $\begin{array}{c}\text { Power } \\
\text { capability } \\
(\mathrm{V}, \mathrm{A})\end{array}$ & $\begin{array}{c}\text { Linearl } \\
\text { trigger }\end{array}$ & Gating & $\begin{array}{c}\text { Conduction } \\
\text { drop }\end{array}$ & $\begin{array}{c}\text { Drop } \\
\text { sensitivity } \\
\text { with }{ }^{\circ} \mathrm{C}\end{array}$ & $\begin{array}{c}\text { Switching } \\
\text { frequency } \\
(\mathrm{KHZ})\end{array}$ \\
\hline GTO & 5000,3030 & Trigger & Currert & Mediurl & Negative & Low \\
BJT & 1400,800 & Linear & Current & Low & Negative & Medium \\
MOSFET & 1000,100 & Linear & Voltage & High & Positive & Very high \\
IGBT & 1200,400 & Linear & Voltage & Mediur & Negative & High \\
MCT & 900,15 ) & Trigger & Voltage & Low & Negative & High \\
\hline
\end{tabular}

At present, the IGBT is the most attractive because it possesses high input impedance and the high speed characteristics of a MOSFET with the conductivity characteristic of a BJT. In the near future, the MCT will be a good candidate for $\mathrm{EV}$ propulsion because it combines high switching speed, high power handling capability, superior dynamic characteristic, and good reliability. Fig. 23 shows an advanced IGBT-based inverter in the Nissan FEV with a maximum output of 60 $\mathrm{kVA}$ and switching frequency of $10 \mathrm{kHz}$ [28]. Another MCT-based inverter with $87.3 \mathrm{kVA}$ and $5 \mathrm{kHz}$ has been tested by the Ford/GE ETX-II. This MCT-based inverter is only $45 \%$ of the BJT-based inverter volume and weighs $28 \%$ less than the BJT-based inverter.

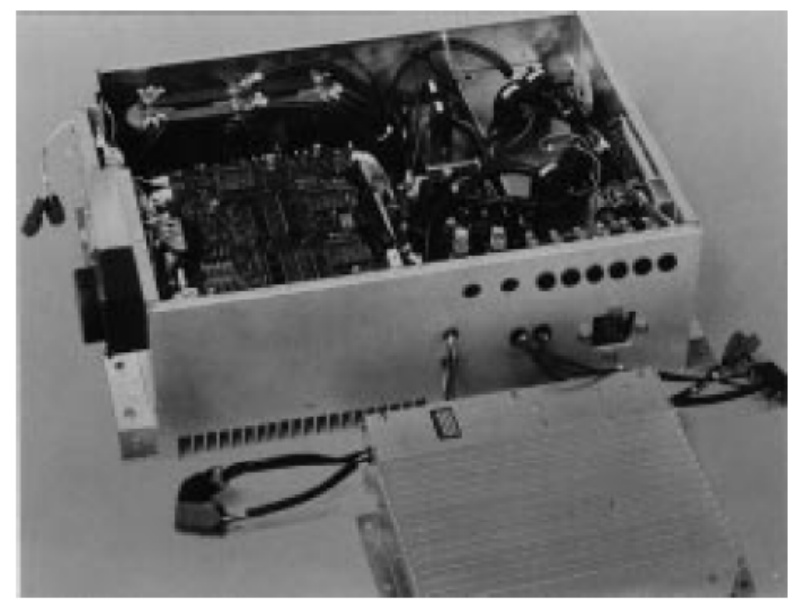

Fig 23. Advanced IGBT-based inverter in Nissan FEV (Courtesy of [19])

The evolution of power converter topologies normally follows that of power devices, aiming to achieve high power density, high efficiency, and robust power converters. dc-dc converters (dc choppers) and dc-ac converters (inverters) are employed for dc and ac motors, respectively. In addition to conventional pulse width modulated (PWM) inverters, one of the latest inverter topologies for battery-fed applications is so-called resonant dc-link inverters. These resonant dc-link inverters have either a parallel or series resonant circuit, thus providing either zero-voltage-switching (ZVS) or zero-current switching (ZCS) condition. Outweighing the additional cost due to the resonant tank and increased control complexity, they have the advantage of zero 
switching loss, low heat sinking requirement, snubberless operation, high power density, less severe EMI problem, very small acoustic noise, and improved reliability. Because of these merits, resonant dc-link inverters have promising applications for EV propulsion.

In addition to converter topologies, another important aspect of power converters is switching schemes. Starting from the last decade, numerous PWM switching schemes have been developed for battery-fed inverters, focusing on harmonic suppression, better utilization of dc-link voltage, suitability for real-time and microcontroller-based implementation, and tolerance of dc-link voltage fluctuation. These schemes can be classified as the voltage-controlled PWM and current controlled PWM. The state-of-the-art voltage-controlled PWM schemes include the natural PWM, regular PWM, optimal PWM, delta PWM, and equal-area PWM. The state-of-the-art current-controlled PWM schemes include the hysteresisband PWM, instantaneous current control with voltage PWM, and space vector PWM. On the other hand, the research on discrete pulse modulation (DPM) schemes for resonant dc-link inverters is becoming attractive.

\section{Conclusion}

In recent years, the increasing importance of power electronics has been realized for energy saving. The high efficiency of power electronics-based energy systems has been discussed in the literature. Saving energy gives a direct financial benefit, particularly where the energy cost is high. The extra cost of power electronics in energy saving can be recovered within a reasonable period depending on the cost of electricity. In addition, reduced consumption means reduced generation that indirectly mitigates the environmental pollution or global warming problem [4]. In general, the integration of renewable energy resources is still not satisfactory. The significance of power electronic was discussed to make the role of power electronics more clear in terms of advancement in inverters, microcontrollers, and high temperature solid state fuel cells. Due to the polluting nature of conventional combustion motors the significance of $\mathrm{EV}$ in mitigating the environmental issues was presented with an emphasis on power electronics.

\section{Acknowledgement}

The authors acknowledge the technical support of Mr Iman Zamani, Brunel University, United Kingdom, during the preparation of this work.

\section{References}

[1] http://en.wikipedia.org/wiki/Renewable_energy.

[2] http://www.oecd.org.

[3] http://www.iea.org.

[4] B. K. Bose, "Global warming: energy, environmental pollution, and the impact of power electronics," IEEE Transactions on Industrial Electronics, vol.4, no.1, 2010, pp. 617. [5]http://www.acclaimlighting.com/\#/accu-ssl-par30/4538182745.

[6]http://www.nae.edu/Publications/Bridge/TheElectricityGrid/ 18587.aspx, Figure2.

[7] V. P. Galigekere, M. K. Kazimierczuk, "Role of Power Electronics in Renewable Energy Systems", Wright State University, pp.2-4.

[8] http://www.itechnews.net/tag/fuel-cell/.

[9]http://en.wikipedia.org/wiki/File:Fuel_Cell_Block_Diagram. svg.

[10] S.C. Singhal, "Advances in solid oxide fuel cell technology,” Elsevier Solid State Ionics, 2000, pp.306.

[11] http://powerelectronics.com/images/micro-inverters-fig10409.jpg.

[12] http://powerelectronics.com/images/micro-inverters-fig30409.jpg.

[13]http://www.conserve-energy-future.com/Images/

Solar_Power.jpg.

[14] http://www.solorb.com/elect/solarcirc/scc3/index.html.

[15] http://www.solorb.com/elect/solarcirc/scc3/sdlc1.jpg.

[16] http://www.solorb.com/elect/solarcirc/spc3/index.html.

[17] http://www.solorb.com/elect/solarcirc/das1/index.html.

[18] M. A. Kromer, J. B. Heywood, "Electric Power trains Opportunities and Challenges in the U.S. Light-Duty Vehicle Fleet”, Sloan Automotive Laboratory, MIT, May 2007, pp.16.

[19] C. C. Chan, K. T. Chau, "An Overview of Power Electronics in Electric Vehicles," IEEE Transactions on Industrial Electronics, vol.44, no.1, Feb. 1997, pp.3-13.

[20] F. Iov, F. Blaabjerg, "Power Electronics for Renewable Energy Systems,” POWERGEN 2009, Lisbon, Portugal, March 18-20, 2009, pp.9-12.

[21] http://www.renewable.moonfruit.com/.

[22]http://powerelectronics.com/power_semiconductors/power_ microinverters_computercontrolled_improve_0409/index.html.

[23] http://en.wikipedia.org/wiki/Fuel_cell.

[24]http://www.loc.gov/rr/scitech/tracer-

bullets/batteriestb.html\#scope.

[25] http://www.itechnews.net/2008/05/18/sony-micro-hybridfuel-cell-system/\#more-10636.

[26]http://www.nae.edu/Publications/Bridge/TheElectricityGrid /18587.aspx.

[27] http://www.solorb.com/elect/solarcirc/scc3/index.html.

[28] S. C. Singhal, "Advances in solid oxide fuel cell technology,” Elsevier Solid State Ionics, 2000, pp.305-313.

[29] B. K. Bose, "Power electronics and motor drives-Recent progress and perspective," IEEE Transactions on Industrial Electronics, vol.56, nol.2, Feb. 2009, pp.581-588.

[30] N. Mohan, T. M. Undeland, and W. P. Robbins, Power Electronics: Converters, Applications, and Design, Third Edition, John Wiley, 2003. 